Tugas Dan Tanggung Jawab Dokter $\mid \mathbf{1}$

\title{
Tugas Dan Tangung Jawab Dokter Menurut Undang-Undang Nomor. 36 tahun 2009 Tentang Kesehatan Dalam Pemberian pelayanan kesehatan Di Kecamatan Sibulue Kabupaten Bone
}

\author{
Nuralim \\ Institut Agama Islam Negeri (IAIN BONE) \\ Nuralim@gmail.com
}

\begin{abstract}
Abstrak
Tujuan penelitian ini untuk mengetahui Tugas dan Tanggung Jawab Dokter Menurut Undang-Undang Nomor 36 Tahun 2009 tentang Kesehatan Dalam Pemberian Pelayanan Kesehatan di Kecematan Sibulue Kabupaten Bone. Pokok permasalahan adalah bagaimana tugas dan tanggung jawab dokter dalam pemberian pelayanan kesehatan menurut Undang-Undang Nomor 36 Tahun 2009 tentang Kesehatan. dan bagaimana bentuk pelaksanaan tanggung jawab dokter di Kecematan Sibulue Kabupaten Bone..metode penelitian yang di gunakan lapangan (Field Research) dengan menggunakan teknik yakni wawancara (interview), dan observasi. Data yang diperoleh diolah dengan teknik metode kualitatif, Selanjutnya dianalisis dengan menggunakan metode analisis deskriptif kualitatif yaitu dengan reduksi data, penyajian data dan penarikan kesimpulan.Hasil penelitian dari peneliti terkait Tugas dan Tanggung Jawab Dokter Menurut Undang-Undang Nomor 36 Tahun 2009 tentang Kesehatan Dalam Pemberian Pelayanan Kesehatan di Kecematan Sibulue Kabupaten Bone yakni Dalam menjalankan tugas dan tangung jawab dokter melakukan pemeriksaan kepada pasien sesuai degan standar oprasional secara berkala untuk memantau perkembangan kondisi yang di alami pasien itu sendiri, melakukan pendekatan kepada masyarakat, memberikan nasehat mengenai pengobtan, pencegahan dan rehabilitasi dengan dibantu oleh rekan medis lainya sesuai dengan bidang keahlianya masing-masing yang di gunakan dalam melakukan pelayanan kepada pasien. Untuk mengatasi permaslahan mengenai penyakit yang dialami masyarakat yaitu melakukan promosi kesehatan karena promosi kesehatan merupakan ujung tombak terhadap semua program kesehatan untuk mewujudkan kesehatan maka promosi kesehatan dilakukan dengan cara advokasi, komunikasi kesehatan dan mobilisasi sosial kepada masyarakat.
\end{abstract}

Kata Kunci : Tugas Dan Tangungjawab Dokter Menurut Undang-UndangNomor. 36 tahun 2009 Tentang Kesehatan Dalam Pemberian pelayanan

Jurnal Al-Dustur; VOLUME 1 NO 1, DESEMBER 2018 
2 | Nuralim

\section{Pendahuluan}

Setiap orang mempunyai hak yang sama dalam memperoleh akses aras sumberdaya dibidang kesehatan. Setiap orang mempunyai hak dalam memperoleh pelayanan kesehatan yang aman, bermutu, dan terjangkau. Setiap orang berhak secara mandiri dan bertanggung jawab menentukan sendiri pelayanan kesehatan yang di perlukan bagi dirinya. ${ }^{1}$

Mengenai kewajiban dokter Leenen membagi kewajiban-kewajiban dokter dalam tiga kelompok, yaitu:

1. Kewajiban yang timbul dari sifat perawatan medis

2. Kewajiban menghargai hak-hak pasien yang bersumber dari hak-hak asasi dalam bidang kesehatan

3. Kewajiban yang berfungsi sebagai fungsi sosial pemeliharaan kesehatan. ${ }^{2}$

Sebagaimana lazimnya suatu perikatan perjanjian medis pun memberikan hak-hak tertentu bagi doter yaitu, hak untuk bekerja sesuai dengan stndar profesi medis, hak menolak melakukan tindakan medis yang tidak dapat dipertanggung jawabkanya secara profesional, hak menolak melakukan tindakan medis yang bertentangan dengan hati nuraninya, hak untuk memilih pasien, hak untuk mengakhiri hubungan dengan pasien apabila kerjasama tidak dimungkinkan lagi, hak atas "privacy", hak atas itikad baik dari pasien dalam memberikan informasi yang berkaitan dengan penyakitnya, hak atas suatu "fair play", hak untuk membela diri, hak untuk menerima honorarium, hak menolak memberikan ksaksian mengenai pasienya di pengadilan. ${ }^{3}$

Tanggung jawab hukum dokter adalah suatu 'keterkaitan" dokter terhadap ketentuan-ketentuan hukum dalam menjalankan profesinya. Tanggung jawab seorang dokter dalam bidang hukum terbagi tiga bagian, yaitu tanggung jawab dokter dalam

\footnotetext{
${ }^{1}$ Muhammad Sadi Is, Etika Hukum Kesehatan Teori dan Aplikasinya di Indonesia, (Cet. I; Jakarta: Kencana, 2015), h. 165.

${ }^{2}$ Danny Wiradarma, Penuntun Hukum Kedokteran, Edisi. 2. (Cet. I; Jakarta: [t.p.], 2014), h. 67. 74.

${ }^{3}$ Danny Wiradarma, Penuntun Hukum Kedokteran, Edisi. 2. (Cet. I; Jakarta: [t.p.], 2014), h. Jurnal Al-Dustur; VOLUME 1 NO 1, DESEMBER 2018
} 
bidang hukum perdata, pidana, dan administrasi. ${ }^{4}$ Tanggung jawab pidana di sini timbul bila pertama-tama dapat dibuktikan apabila adanya kesalahan profesional, misalnya kesalahan dalam diagnosis atau kesalahan dalam cara-cara pengobatan atau perawatan. Dari segi hukum, kesalahan atau kelalaian akan selalu berkait dengan sifat melawan hukumnya suatu perbuatan yang dilakukan oleh orang yang mampu bertanggung jawab apabila dapat menginsafi makna yang kenyataanya dari perbuatanya, dan menginsafi perbuatanya itu tidak di pandang patut dalam pergaulan masyarakat dan mampu untuk menentukan niat atau kehendaknya dalam melakukan perbuatan tersebut. ${ }^{5}$

Sehubungan dengan kemampuan bertanggung jawab ini, dalam menetukan bahwa sesorang itu bersalah atau tidak perbuatan yang dilakukanya itu merupakan perbuatan yang di larang dalam Undang-undang dan adanya hubungan batin antara pelaku dan perbuatan yang dilakukan yaitu berupa dolus (kesenjangan) atau culpa (kelalaian/kelupaan) serta tidak adanya alasan pemaaf. Mengenai kelalaiaan (neglience) mencakup dua hal yaitu karena melakukan sesuatu yang tidak seharusnya tidak dilakukan atau karena tidak melakukan sesuatu yang seharusnya dilakukan. ${ }^{6}$ Ada perbedaan kepentingan antara tindak pidana biasa dan' 'tindak pidana medis'. Pada tindak pidana yang terutama diperhatikan yaitu' akibatnya', sedangkan pada tindak pidana medis yaitu' penyebabnya'. Walaupun berakibat fatal, tetapi jika tidak ada unsur kelalaian atau kesalahan maka dokternya tidak dapat di persalahkan. Beberapa contoh dari criminal malpractice yang berupa kesengjangan yaitu melakukan aborsi tanpa indikasi medis, membocorkan rahasia kedokteran, tidak melakukan pertolongan seseorang yang dalam keadaan emergency, melakukan euthanasia, menerbitkan surat keterangan yang tidak benar, dan memberikan keterangan yang tidak benar, di sidang pengadilan dalam kapasitas sebagai ahli. ${ }^{7}$

Permasalahan utama dalam pelayanan kesehatan saat ini yaitu belum teratasinya penyakit yang dialami oleh masyarakat yang disebabkan oleh tenaga medis sangat terbatas dan peralatan yang kurang memadai. Untuk mengatasi permasalahan kesehatan yang dialami oleh masyarakat perluadanya kebijakan dengan

\footnotetext{
${ }^{4}$ Muhammad Sadi Is, Etika Hukum Kesehatan Teori dan Aplikasinya di Idonesia, h. 103.

${ }^{5}$ Muhammad Sadi Is, Etika Hukum Kesehatan Teori dan Aplikasinya di Idonesia, h. 103.

${ }^{6}$ Muhammad Sadi Is, Etika Hukum Kesehatan Teori dan Aplikasinya di Idonesia, h. 103.

${ }^{7}$ Muhammad Sadi Is, Etika Hukum Kesehatan Teori dan Aplikasinya di Idonesia, h. 104. Jurnal Al-Dustur; VOLUME 1 NO 1, DESEMBER 2018
} 
mempertimbangkan permasalahan yang dihadapi oleh masyarakat sehingga dokter memiliki peranan penting dalam menjalankan tugas dan tanggung jawabnya dalam pemberian pelayanan kepada masyarakat.

Berdasarkan dari uraian diatas, maka penulis merasa tertarik untuk mengkaji lebih jauh terkait dengan kinerja dokter dalam pemberian pelayanan kesehatan kepada masyarakat sesuai dengan Undang-Undang Nomor 36 Tahun 2009 Tentang Kesehatan. Sehingga permasalahan ini diangkat dalam skripsi dengan judul "tugas dan tanggungjawab dokter menurut Undang-Undang nomor 36 Tahun 2009 Tentang Kesehatan dalam pemberian pelayanan kesehatan di kecematan sibulue Kabupaten B one"'

Kesehatan adalah keadaan sejahtra dari badan, jiwa dan sosial yang memungkinkan setiap orang hidup produktif secara sosial dan ekonomis. ${ }^{8}$

\section{Tujuan Penelitian}

Berdasarkan rumusan masalah yang telah dikemukakan sebelumnya peneliti dapat menentukan tujuan penelitian yaitu sebagai berikut:

a) Untuk mengetahui tugas dan tanggung jawab dokter dalam pemberian pelayanan kesehatan menurut Undang-Undang Nomor 36 Tahun 2009 Tentang Kesehatan?

b) Untuk mengetahui bentuk pelaksanaan pelayanan kesehatan di kecematan sibulue.

\section{Kegunaan penelitian}

Seperti halnya tujuan yang akan dicapai dalam pembahasan draf ini, penulis sangat berharap agar penelitian yang dilakukan mempunyai keguanaan. Adapun kegunaan yang hendak dicapai dalam penelitian draf ini adalah:

${ }^{8}$ Muhammad Sadi Is, Etika Hukum Kesehatan Teori dan Aplikasinya di Idonesia, h. 161. Jurnal Al-Dustur; VOLUME 1 NO 1, DESEMBER 2018 
a) Secara teoritis penelitian ini berguna untuk memperkaya wacana keilmuan khususnya kajian Hukum dalam bidang studi Hukum Tata Negara dan menambah bahan pustaka bagi perpustakaan Sekolah Institut Agama Islam Negeri Bone (IAIN Bone)

b) Secara praktis kegunaan penelitian ini dapat menjadi sumbangan pemikiran serta masukan tentang tugas dan tangung jawab dokter dalam pemberian pelayanan kesehatan di kecematan sibulue.

\section{Tinjauan Pustaka}

Tinjauan pustaka merupakan penelahan terhadap hasil penelitian terdahulu yang memiliki kesamaan topik, dan berguna pula untuk memberikan gambaran bahwa penelitian yang dilakukan bukan merupakan plagiat. Dalam Kamus Besar Bahasa Indonesia diuraikan bahwa plagiat merupakan pengambilan karagan atau pendapat orang lain dan menjadikanya seolah-olah karangan atau pendapatnya sendiri. ${ }^{9}$

Dalam penyusunan draft skripsi ini, peneliti membutuhkan literatur yang dapat dijadikan sebagai bahan rujukan dalam penelitian. Literatur yang dimaksud adalah sumber bacaan beruppa karya ilmiah berupa skripsi yang telah ada sebelumnya dan buku-buku yang memeiliki korelasi yang relavan dengan penelitian ini, yaitu diantaranya sebagai berikut:

1. Safrowi dalam skripsinya berjudul "Perlindungan Hukum terhadap Profesi Dokter Terkait Dugaan Malapraktek Medik (Tinjauan Hukum Pidana Positif dan Hukum Pidana Islam)"'. Hasil penelitian tersebut menjelaskan mengenai perlindungan hukum dalam ketentuan hukum positif dan hukum Islam, bentuk pertanggung jawaban dokter terhadap pasien dalam upaya pelayanan medik, dan sengketa medik atau dugaan malpraktek di lingkungan rumah sakit. ${ }^{10}$

\footnotetext{
${ }^{9}$ Pusat Bahasa Depertemen Pendidikan Nasional, Kamus Besar Bahasa Indonesia, h. 881.

${ }^{10}$ Safrowi," Perlindungan Hukum Terhadap Profesi Dokter Terkait Dugaan Malpraktek Medik (Tijauan Hukum Pidana Positif dan Hukun Pidana Islam)" (Skripsi, UIN Syarif Hidayatullah Jakarta), 2010, h. 86. 
6 | Nuralim

2. dr.H.Yunanto,Sh dalam tesis yang berjudul "Pertanggung jawaban Dokter dalam Transaksi Terapeutik' . Hasil penelitian tersebut menjelasakan mengenai hubungan hukum antara dokter dengan pasien dalam transaksi terapiutik, pennyelesaian perkara-perkara ingkar janji/wanprestasi dan perbuatan melanggar hukum yang dilakukan oleh dokter dalam transaksi terapeutik, dan peranan IDI dalam rangka membantu penyelesaian maslah pada kasus-kasus malpraktek. Dengan demikian, hal yang diperoleh dalam penelitian adalah hubungan hukum antara dokter dengan pasien dalam taransaksi terapeutik dapat terjadi karena adanya perjanjian Undang-Undang. Walapun secara teori kedudukan pasien dan dokter sama secara hukum, namun kurangnya pemahanman hukum mengenai hak dan kewajiban masing-masing pihak, pelanggaran-pelanggaran masih terjadi dan pasienlah yang dirugikan. Karena pasien dalam posisinya dalam keadan lemah dan pasrah untuk mengiba pertolongan medis, denagn secara terpaksa pasien mau menandatangani persetujuan itu demi memperoleh pelayanan medis. ${ }^{11}$

\section{Kerangka Pikir}

Berdasarkan uaraian yang telah dikemukakan di atas, maka pada bagian ini diuraikan kerangka pikir yang peneliti jadikan sebagai pedoman dan landasan berfikir dalam melaksanakan penelitian ini. Hal ini perlu dikembangkan karena berfungsi mengarahkan peneliti untuk memperoleh data dan informasi yang diperlukan guna memecahkan masalah penelitian secara ilmiah.

Pada umumnya kerangka pikir dapat dibuat secara narasi atau degan cara skema, namun dalam skripsi ini peneliti mengunakan bentuk skema ada pun kerangka pikir yang dimaksud adalah:

${ }^{11}$ Dr.H.Yunanto,SH, Pertanggungjawaban Dokter dalam Transaksi Terapeutik ( Tesis, Pascasarjana Universitas Diponegoro Semarang), 2009, h. 125.

Jurnal Al-Dustur; VOLUME 1 NO 1, DESEMBER 2018 


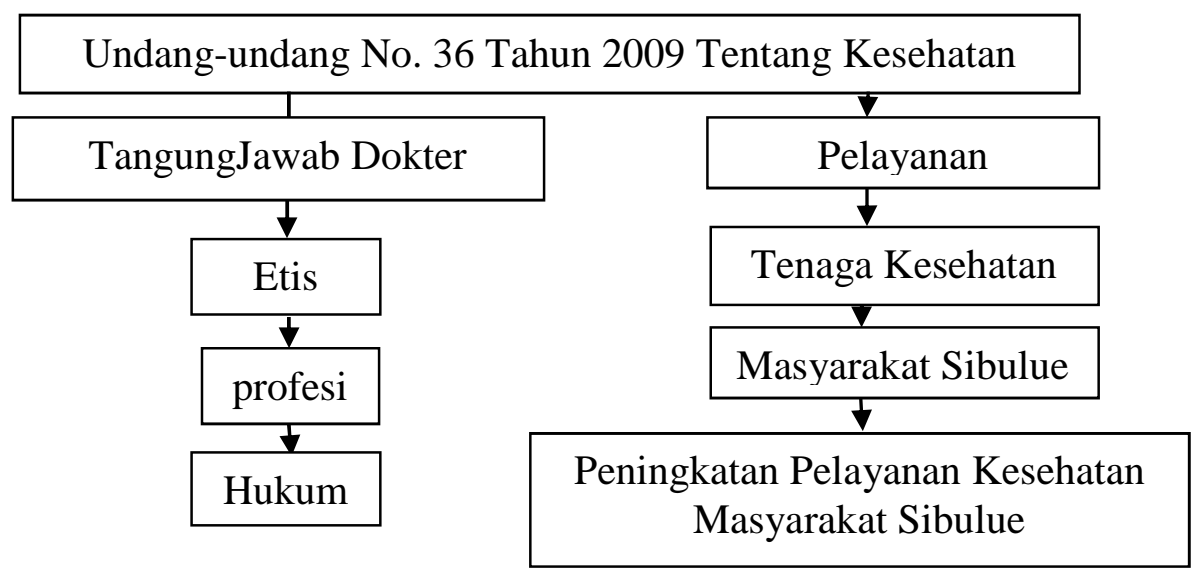

\section{Metode Penelitian}

\section{Jenis dan Pendekatan Penelitian}

Jenis penelitian ini adalah field research (riset lapangan) yaitu pengumpulan data degan cara peneliti terjun langsung ke lapagan penelitian untuk melakukan penelitian degan mengunakan salah satu atau beberapa metode observasi, metode interview. ${ }^{12}$ Dalam penelitian awal, peneliti menggunakan metode observasi dan interview, peneliti melakukan wawancara degan dokter dan pasien untuk memperoleh infrormasi dalam penelitian ini.

Pendekatan penelitian merupakan proses kegiatan penyelidikan, pengumpulan, pengelolaan, analisis, dan penyajian data yang dilakukan secara sistematis dan objek untuk memecahkan suatu persoalan sesuai objek yang diteliti. ${ }^{13}$

Adapun pendekatan peneliti yang digunakan dalam penulisan ini yaitu pendekaatan penelitian hukum yuridis empiris atau sosiologis hukum adalah pendekatan dengan melihat suatu dengan kenyatan hukum di dalam masyarakat, pendekatan sosiologis hukum merupakan pendekatan yang digunakan untuk melihat aspek-aspek hukum dalam interaksi sosial dalam masyarakat dan berfungsi sebagai

\footnotetext{
${ }^{12}$ Abdullah k., Tahapan dan Langkah-langkah Penelitian (Cet. I; [t.p]: Luqman al-Hakim
} Press, 2013), h. 28.

\footnotetext{
${ }^{13}$ Pusat Bahasa Depertemen Pendidikan Nasional, Kamus Besar Bahasa Indonesia h. 1163 Jurnal Al-Dustur; VOLUME 1 NO 1, DESEMBER 2018
} 
penunjang untuk mengidentifikasi dan mengklarifikasi temuan bahan non hukum bagi keperluan penelitian atau penulisan hukum. ${ }^{14}$

\section{Lokasi Penelitan}

Adapun menjadi titik fokus dalam penelitian ini sebagai lokasi penelitian adalah Pusat Kesehatan Masyarakata Sibulue yang berlokasi di JL. Poros Pattiro Bajo, Kecematan Sibulue, Kabupaten Bone.

\section{Data dan Sumber Data}

Data adalah fenomena yang dicari untuk dipelajari, fenomena yang diamati, dicatat, dan setelah diketahui menjadilah informasi sebagai dasar yang obyektif dalam pembuktian, pengambilan keputusan dan kesimpulan. ${ }^{15}$ Sumber data merupakan semua informasi baik yang berupa benda nyata, sesuatu yang abstrak, peristiwa/gejala baik secara kualitatif. Sumber data kualitatif adalah sumber data yang disuguhkan dalam dua bentuk parameter ' abstrak'. 16

Dalam penelitian ini, data penelitian menjadi valid dan akurat maka peneliti menggunakan dua sumber yaitu:

a) Data primer adalah data yang diperoleh langsung pada subjek sebagai sumber informasi yang ingin dicapai ${ }^{17}$. Data primer dalampenelitian ini diperoleh langsung dari lokasi penelitian yaitu melalui observasi dan wawancara. Adapun yang terkait adalah tenaga medis dan pasien yang berada di lingkungan pusat kesehatan masyarakat sibulue.

b) Data skunder merupakan data yang diperoleh dari bahan pustaka yang korelasi/relavan dan dapat dijadikan penunjang dalam penulisan skripsi. Data skunder dalam penelitian ini yang dimaksud adalah bahan bacaan baik majallah, koran, artikel, tesis, disertasi, buku bacaan maupun literatur yang lain. 18

${ }^{14}$ Zainuddin Ali, Metode Penelitian Hukum Edisi. I (Cet. V; Jakarta: Sinar Grafika, 2014), h. 105

${ }^{15}$ Abdullah K., Tahapan dan Langkah-Langkah Penelitian h. 40.

${ }^{16}$ Sukandarumidi, Metodologi penelitian: petunjuk praktis untuk peneliti pemula (Cet. IV; Jogjakarta: Gadjah Mada University Press, 2012), h. 133.

${ }^{17}$ Abdullah K., Tahapan dan Langkah-Langkah Penelitian h. 41.

${ }^{18}$ Abdullah K., Tahapan dan Langkah-Langkah Penelitian h. 41. Jurnal Al-Dustur; VOLUME 1 NO 1, DESEMBER 2018 


\section{Instrumen Penelitian}

Dalam penelitian ini, menggunakan beberapa instrumen yang bertujuan untuk memudahkan memperoleh data dan informasi yang dibutuhkan. Adapun instrumen yang digunakan, adalah sebagai berikut.

a) Pedoman wawancara adalah alat yang digunakan dalam mengumpulkan data berupa sejumlah pertanyaan yang berkaitan degan informasi yang dibutuhkan dalam penelitian.

b) Pedoman observasi berisi sebuah daftar jenis kegiatan yang mungkin timbul dan akan diamati. $^{19}$

\section{Teknik Pengumpulan Data}

Dalam pengumpulan data, peneliti menggunakan beberapa teknik antara lain sebagai berikut:

a) Interview/wawancara

Interview adalah metode pengumpulan data degan jalan tanya jawab antara dua pihak (pencari informasi dan pemberi informasi). Prosedur wawancara melibatkan situasi face to face dimana pewawancara menayakan sejumlah pertanyaan kepada orang lain guna memperoleh jawaban yang relavan dengan tujuan wawancara. Teknik ini juga didasarkan pada self-report. ${ }^{20}$

b) Observasi

Observasi adalah metode pengumpulan data degan jalan pengamatan dan pencatatan secara sistematik fenomena-fenomena yang diteliti. ${ }^{21}$ Observasi $^{2}$ diartikan sebagai pencatatan secara sistematis terhadap gejala-gejala yang tampak pada obyek penelitian atau studi yang disengaja dan sistematis tentang fenomena sosial dan gejala-gejala psikis dengan jalan pengamatan dan pencatatan. $^{22}$

\section{Teknik Analisis Data}

\footnotetext{
${ }^{19}$ Suharsimi Arikunto, Prosedur Penelitian: Suatu Pendekatan praktek (Cet. XII; Jakarta: Rineka Cipta, 2002), h.133

${ }^{20}$ Nyayu Khodija, Psikologi Pendidikan (Cet. II; Jakarta: Rajagrafindo Persada, 2014), h. 31.

${ }^{21}$ Nyayu Khodija, Psikologi Pendidikan h. 32.

${ }^{22}$ Abdullah K., Tahap dan Langkah-langkah Penelitian h. 43. Jurnal Al-Dustur; VOLUME 1 NO 1, DESEMBER 2018
} 
$\mathbf{1 0}$ | Nuralim

Analisis data dapat dilakukan dengan tiga cara sebagai berikut. ${ }^{23}$

a) Reduksi Data

Data yang diperoleh di lapangan disusun dalam bentuk uraian yang lengkap dan banyak. Data tersebut direduksi, dirangkum, dipilih hal-hal yang pokok, dan difokuskan pada hal-hal yang penting dan berkaitan dengan masalah.

b) Display/Penyajian Data

Analilisis ini dilakukan mengingat data yang terkumpul itu sangat banyak. Data yang tertumpuk dapat menimbulkan kesulitan dalam menggambarkan rincinya secara keseluruhan dan sulit pula untuk mengambil kesimpulan. Kesulitan ini dapat diatasi dengan cara membuat model, matriks atau grafik sehingga keseluruhan data dan bagian-bagian detailnya dapat dipetahkan dengan jelas.

c) Verifikasi dan Kesimpulan

Data yang sudah dipolakan, kemudian difokuskan dan disusun secara sistematis, baik melalui penentuan tema maupun model grafik atau juga matriks. Kemudian melalui reduksi data tersebut disimpulkan sehingga makna data dapat ditemuka

\section{Hasil Penelitian}

\section{Pelaksanaan Tugas dan Tanggung Jawab Dokter dalam Pemberian Pelayanan Kesehatan}

Yang melatar belakangi munculnya Undang-Undang Nomor 36 Tahun 2009 adalah karena adanya lima dasar pertimbangan perlunya dibentuk undang-undang kesehatan tersebut yaitu pertama; kesehatan adalah hak asasi dan salah satu unsur kesejahtraan, Kedua; prinsip kegiatan kesehatan yang nondeskriminatif, partisipatif dan berkelanjutan. Ketiga; kesehatan adalah investasi artinya dalam suatu kondisi dalam tubuh apabila tubuh kestiakn maka kita tidak akan mampu melakukan aktifitas. Keempat; pembangunan kesehatan adalah tanggungjawab pemerintah dan masyarakat, dan yang Kelima; bahwa Undang-Undang Nomor 23 Tahun 1992 sudaah tidak sesuai lagi dengan perkembangan, tuntutan dan kebutuhan hukum dalam masyarakat (Undang-Undang Nomor 36 Tahun 2009 tentang Kesehatan). ${ }^{24}$

\footnotetext{
${ }^{23}$ Dadang Kahmad, Metode Penelitian Agama (Cet. I; Bandung: Pustaka Setia, 2000), h. 103

24 Adik Wibowo. Kesehatan Masyarakat di Indonesia, (Cet I; Jakarta : PT Raja Grafindo Persada, 2014), h. 33.
} 
Untuk mencapai tujuan nasional diselenggarakan upaya pembangunan yang berkesinambungan merupakan suatu rangkaian pembangunan yang menyeluruh terarah dan terpadu, termasuk diantaranya pembangunan kesehatan. Kesehatan merupakan hak asasi manusia dan salasatu unsur kesejahtraan yang harus diwujudkan sesuai degan cita-cita bangsa indonesia sebagaimana yang dimaksud didalam pancasila dan pembukaan undang-undang dasar negara republik indonesia tahun 1945. Bahwa hal ini menandakan adanya niat ingin melakukan perubahan paradigma, upaya pembangunan kesehatan yaitu dari paradigma sakit yang begitu kental dari Undang-Undang kesehatan menjadi paradigma sehat.

Untuk mewujudkan pelayanan kesehatan yang baik, dibentuk UndangUndang Nomor 36 Tahun 2009 tentang Kesehatan. Undang-Undang tersebut mengatur secara jelas, Cermat, dan lengkap setiap aspek kesehatan, mulai dari pengertian penting tentang kesehatan, asas-asas dan tujuan, hak dan kewajiban, tangungjawab pemerintah, sumberdaya dibidang kesehatan, upaya kesehatan, kesehatan ibu, bayi, anak, remaja, lanjut usia, dan penyandang cacat, gizi, kesehatan jiwa, penyakit menular dan penyakit tidak menular, kesehatan lingkungan, kesehatan kerja, pengelolaan kesehatan, informasi kesehatan, peran serta masyarakat, badan pertimbangan kesehatan, pembina dan pengawasan dan berbagai hal yang berkaitan dengan yang diatur dalam setiap babnya.

Dalam menjalankan tugas dan tangung jawab dokter melakukan pemeriksaan kepada pasien sesuai degan standar oprasional secara berkala untuk memantau perkembangan kondisi yang di alami pasien itu sendiri, melakukan pendekatan kepada masyarakat, memberikan nasehat mengenai pengobtan, pencegahan dan rehabilitasi dengan dibantu oleh rekan medis lainya sesuai dengan bidang keahlianya masing-masing yang di gunakan dalam melakukan pelayanan kepada pasien', 25

Gambaran peristiwa tersebut memperjelas bahwa Dokter dalam melaksanakan tugasnya, sebagai dokter terlebih dahulu melakukan pemeriksaan secara berkala kepada pasien, memberikan arahan kepada pihak keluarga dan pasien mengenai pencegahan terhadap penyakit yang dialami pasien tersebut, menyelenggarakan rekan medis yang memenuhi standar, dan mebina keluarga pasien itu sendiri guna untuk mempermudah, menguragi rasa kekhawatiran terhadap

\footnotetext{
${ }^{25}$ Anugrah T.Lando, Dokter UPTD Puskesmas Sibulue, Kec. Sibulue Kab. Bone, Sulsel, wawancara oleh penulis di UPTD Puskesmas Sibulue, 21 Oktober 2017 Jurnal Al-Dustur; VOLUME 1 NO 1, DESEMBER 2018
} 
keluarga pasien mengenai penyakit yang dialami serta mempercepat pemulihan kesehatan pasien.

Pada dasarnya pemeriksaan kepada pasien tidak dilakukan untuk menegakkan diagnosis dari penyakit yang dialami oleh pasien itu sendiri. Dengan demikian, keberhasilan dari suatu program untuk mengetahui suatu penyakit sangat bergantung kepada pemeriksaan lanjutan yang akan dilakukan untuk memastikan kebenara terhadap suatu penyakit maka dilakukan diagnosis. Apakah populasi dengan hasil positif tersebut mampu menjalani pemeriksaan untuk diagnosis secara pasti yang terkadang memerlukan biaya yang mahal dan terkadang lebih invasiv lalu dilanjutkan dengan pengobatan yang sesuai.

Mengenai tangungjawab dokter sebagai tenaga yang memilki profesi dalam tindakan medis terdiri dari beberapa tangungjawab diantaranya sebagai berikut

1. Tangung jawab Etis

Dalam hubungan sosial, manusia dibatasi oleh norma-norma yang mengatur sikap dan tingkah laku mereka dalam pergaulan di tengah masyarakat. Agar terjadi keseimbangan kepentingan masing-masing hubungan antara dokter dengan pasien maupun dengan masyarakat, akan selalu dibatasi oleh norma atau kaidah yang akan dipakai sebagai tolak ukur untuk menilai sesuatu. ${ }^{26}$

Dari hasil wawancara yang dilakukan oleh penulis kepada salasatu informan mengatakan bahwa :

Dokter dalam menjalakan profesinya sebagai seorang dokter beliau sopan, baik, ramah,serta memilki perilaku yang baik dalam menjalankan tugasya sebagai sorang dokter memberikan pelayanan kepada pasienya sendiri sesuai dengan kode etik yang dimiliki seorang dokter dalam menjalankan tanggungjawabnya. ${ }^{27}$

Berdasarkan dari hasil wawancara penulis maka dapat dijelaskan bahwa di UPTD Puskesmas Sibulue dokter menjalankan profesinya sebagai seorang dokter dalam memberikan pelayanan kepada pasien sesuai dengan etika sebagai seorang dokter yang memilki kesadaran hukum dan kepedulian sosial yang berlandaskan dengan etika yang dapat dirumuskan

\footnotetext{
${ }^{26}$ Yuanto. Pertangungjawaban Dokter dalam Transaksi Terapiutik, h. 66.

${ }^{27}$ Fatimah. Pasien UPTD Puskesmas Sibulue, Kec. Sibulue Kab. Bone, Sulsel, Wawancara oleh penulis di UPTD Puskesmas Sibulue, 21 Oktober 2017.

Jurnal Al-Dustur; VOLUME 1 NO 1, DESEMBER 2018
} 
sebagai suatu kegiatan pelayanan di dalam bidang kesehatan melalui keilmun yang dimilikinya.

2. tangung jawab profesi

Semua profesi memilki resiko yang harus dihadapi karena negara kita adalah negara yang berdasakan hukum maka tidak ada orang yang kebal terhadap hukum, sehingga penegakan hukum harus harus pula kita hormati. Agar seseorng yang memilki profesi tidak berbuat sewenang-wenag terhadap orang lain. Karena tanggungjawab profesi merupakan suatu perbuatan yang harus dilakukan dan tidak boleh tidak dilakukan apabila tidak dilakukan maka bisa menimbulkan akibat hukum.

Dari hasil wawancara yang dilakukan oleh penulis kepada salasatu informan mengatakan bahwa :

Dokter dalam menjalankan profesinya sebagi seorang dokter memberikan perawatan yang sebagaiman mestinya, memberikan informasi mengenai bagaimana cara yang dilakukan untuk melakukan hal dalam pencegahan terhadap penyakit yang dialami serta memberikan perawatan yang baik kepada pasienya sendiri. ${ }^{28}$

Dari pernyataan tersebut bahwa dokter dalam melaksanakan tangung jawabnya sebagai seorang dokter di UPTD puskesmas sibulue memberikan arahan mengenai penyembuhan yang akan dijalankan oleh pasienya serta memberikan informasi kepada pasienya mengenai penyakit yang dialami oleh pasien, dokter dalam perawatan mengusahakan sekecil-kecilnya dalam derajat resiko yang dapat terjadi sehinnga pasien diberikan pilihan alternatif dari perawatan yang akan diberikan oleh dokter kepada dirinya sendiri

3. Tangung jawab Hukum

Siapa saja khususnya kepada pasien sebab jika pasien menderita kerugain akibat tindakan kelalaian tenaga kesehatan maka mendapat ganti kerugian sebagaiman yang terdapat dalam pasal 29 dan pasal 58 Undangundang Nomor 36 Tahun 2009 tentang Kesehatan. Pasal 29 menentukan bahwa dalam hal tenaga kesehatan di duga dalam melakukan kelalaian dalam menjalankan profesinya, kelalaian tersebut harus diselesaikan melalui mediasi. Pasal 58 mengatur mengenai hak setiap orang untuk menuntut ganti rugi terhadap seseorang, tenaga kesehatan, dan atau penyelenggara

\footnotetext{
${ }^{28}$ Rosmiati. Pasien UPTD Puskesmas Sibulue, Kec. Sibulue Kab. Bone, Sulsel, Wawancara oleh penulis di UPTD Puskesmas Sibulue, 21 Oktober 2017.

Jurnal Al-Dustur; VOLUME 1 NO 1, DESEMBER 2018
} 
kesehatan yang menimbulkan kerugian akibat kesalahan atau kelalaian dalam pelayanan kesehatan yang diterimanya. ${ }^{29}$ Berdasar dari ketentuan tersebut, terlihat bahwa penuntutan ganti kerugian ini, baik yang diakibatkan sebagai kesalahan (kesengajaan) atau kelalaian dalam pelayanan kesehatan dan penuntutan ditunjukan kepada seseorang tenaga kesehatan maupun kepada pihak penyelenggara kesehatan.

Terdapat kelalaian tenaga kesehatan yang tepat menjadi tangung jawab tenaga kesehatan yang bersangkutan. Implikasi kepada pasien (masyarakat), yaitu pasien harus mengetahui bahwa telah terjadi kelalaian tenaga kesehatan yang menimbulkan kerugian kepadanya. Peran perawatan dan peran koordonatif adalah tanggungjawab mandiri, sementara tangung jawab terapiutik adalah mendampingi atau membantu dokter dalam melaksanakan tugas kedokteran, yaitu diagnosis, terapi, maupun tindakan-tindakan medis.

Hukum perdata yang dimaksud dalam suatu pertanggung jawaban tindakan medis adalah adanya unsur ganti-rugi jika dalam suatu tindakan medis terdapat suatu kelalaian atau kesalahan yang dilakukan oleh tenaga medis. Hukum perdata ini, juga dikaitkan dengan isi Undang-undang Republik Indonesia No. 36 tahun 2009 pasal 29 yang menyebutkan bahwa 'Dalam hal tenaga kesehatan diduga melakukan kelalaian dalam menjalankan profesinya, kelalaian tersebut harus diselesaikan terlebih dahulu dengan cara mediasi. " Dimana yang dimaksud dalam mediasi ini adalah suatu rangkaian proses yang harus dilewati oleh setiap perkara sebelum masuk kepengadilan. ${ }^{30}$

Dalam pelanggaran hukum administrasi adalah pelanggaran terhadap hukum yang mengatur hubungan hukum antara jabatan-jabatan dalam negara. Dalam lingkungan kesehatan, hukum administrasi terkait erat dengan adanya surat izin praktek yang dimiliki oleh tenaga kesehatan baik dokter dan perawat. Dasar dari adanya hukum administrasi ini, yaitu Undangundang No. 39 Tahun 2009 Tentang Kesehatan, yaitu pasal 23 ayat (3) dan pasal 24 ayat (1). Bagi tenaga dokter hal ini diatur pula dalam Permenkes RI 512/2007 pasal 2 ayat (1) yang menyebutkan bahwa "Setiap dokter dan dokter gigi yang akan melakukan praktik kedokteran wajib memiliki SIP.

\footnotetext{
${ }^{29}$ Adik Wibomo, Kesehatan Masyarakat di Indonesia h. 496.

${ }^{30}$ Muhammad Sadi Is, Etika Hukum Kesehatan dan Teori dan Aplikasi di Indonesia h. 103. Jurnal Al-Dustur; VOLUME 1 NO 1, DESEMBER 2018
} 
Dari hasil wawancara yang dilakukan oleh penulis kepada salasatu informan mengatakan bahwa :

Untuk mengatasi permaslahan mengenai penyakit yang dialami masyarakat yaitu melakukan promosi kesehatan karena promosi kesehatan merupakan ujung tombak terhadap semua program kesehatan untuk mewujudkan kesehatan maka promosi kesehatan dilakukan dengan cara advokasi, komunikasi kesehatan dan mobilisasi sosial kepada masyarakat. ${ }^{31}$

Dari pernyatan tersebut bahwa dalam mengatasi permasalahan penyakit yang dialami oleh pasien itu sendiri yaitu dilakuakanya berbagai cara seperti advokasi, komunikasi kesehatan dan mobilisasi sosial kepada masyarakat dalam upaya untuk mengatasi permasalahan tersebut.

Advokasi kesehatan sebagai upaya kesehatan yang diharapakan mampu memberikan dukungan terhadap uapaya kesehatan sebagai penentu kebijakan dalam pemerintahan, yang berpotensi mendukung upaya kesehatan dalam mengidentifikasi masalah serta memantau evaluasi agar terjandi tindak lanjut dalam maslah tersebut. Komunikasi kesehatan merupakan strategi untuk menyebar luaskan informasi mengenai kesehatan dan pemeliharaan kesehatan meliputi informasi mengenai pencegahan penyakit, kebijaksanaan dalam pemeliharaan kesehatan yang mampu sejauh mungkin merubah maslah kesehatan yang terjadi.

Dalam Undang-undang Nomor 36 tahun 2009 tentang kesehatan Pasal 52 ayat (1) menjelaskan bahwa pelayanan kesehatan terdiri dari pelayanan kesehatan perseorangan dan pelayanan kesehatan masyarakat. Di dalam pelayanan kesehatan perseoranganterdiri dari. ${ }^{32}$

1. pelayanan pemeriksaan umum

2. pelayanan kesehatan gigi dan mulut

3. pelayanan manejemen terpadu balita sakit (MTBS)

${ }^{31}$ Ambo Tang, Promosi Kesehatan UPTD Puskesmas Sibulue, Kec. Sibulue Kab. Bone, Sulsel,wawancara oleh penulis di UPTD Puskesmas Sibulue, 21 Oktober 2017.

${ }^{32} \mathrm{https} / / /$ googleweblight.com/?

lite_url=https://puskesmasmadurejo.wordpress.com/penyelenggaraan-upayakesehatanperorangan $/ \&$

ei $=$ y2SgZlAF $\& l c=i d-$

ID\&s=1\&m=808\&host=www.google.co.id\&ts=1508764643\&sig=ANTY_L277CHnxKSEZc QdDEeiDFE

RiCxUVQ

Jurnal Al-Dustur; VOLUME 1 NO 1, DESEMBER 2018 
16 | Nuralim

4. Pelayanan KIA-KB yang bersifat UKP

5. Pelayanan Gizi

6. Pelayanan loket Obat

7. Pelayanan persalinan

Pelayanan kesehatan masyarakat merupakan kebutuhan dasar manusia merupakan unsur-unsur yang dibutuhkan manusia dalam mempertahankan keseimbangan fisiologis maupun psikologis yang bertujuan mempertahankan kehidupan dan kesehatan dalam menjalankan segala aktifitasnya.

\section{Kesimpulan}

Berdasarkan pembahasan yang telah penulis lakukan di UPTD Puskesmas sibulue mengenai tugas dan tanggungjawab dokter dalam pemberian pelayan kesehatan. Maka penulis menarik suatu kesimpulan yang dirumskan dengan hasil pembahasan yaitu sebagai berikut :

Dalam menjalankan tugas dan tangungjawab dokter melakukan pemeriksaan kepada pasien sesuai degan standar oprasional secara berkala untuk memantau perkembangan kondisi yang di alami pasien itu sendiri, melakukan pendekatan kepada masyarakat, memberikan nasehat mengenai pengobtan, pencegahan dan rehabilitasi dengan dibantu oleh rekan medis lainya sesuai dengan bidang keahlianya masing-masing yang di gunakan dalam melakukan pelayanan kepada pasien.Mengenai prosedur pelayanan yang ada di UPTD Puskesmas sibulue sudahdapat dikatakan cukup baik, dengan mengikuti prosedur yang ada di UPTD Puskesmas sibulue masyarakat dapat memperoleh pelayanan yang ada di UPTD Puskesmas Sibulue. Berdasarkan upaya yang dilakukan dalam peningkatan kesehatan masyarakat yang ada di UPTD Puskesmas sibulue melakukan promosi kesehatan kepada masyarakat yang berobat di UPTD Puskesmas sibulue.

\section{Referensi}

A.W.Widjaja. Etika Administrasi Negara. Cet. III;Jakarta:Sinar Grafika Offset,2004. Abdullah bin Ali Al-Ju'aitsan. Rahasia di Balik Penyakit Hiburan Bagi Orang Sakit, Cet. I; Jakarta: PT. Al-Mawardi Prima Anggota IKAPI JAYA, 2004.

Abdullah k., Tahapan dan Langkah-langkah Penelitian Cet. I; [t.p]: Luqman alHakim Press, 2013. 
Arikunto Suharsimi, Prosedur Penelitian: Suatu Pendekatan praktek Cet. XII; Jakarta: Rineka Cipta, 2002.

Azra Azyumardi. Histografi Islam Kontenporer, Cet.I; Jakarta: PT Gramedia Pustaka Utama, 2002.

B. Boediono. Pelayanan Prima Perpajakani Cet. II; Jakarta: PT Asdi Mahasatya, 2003.

Bungin Burhan, Analisis Data Penelitian Kualitatif Jakarta: PT Raja Grafindo Persada, 2003.

Dr.H.Yunanto,SH, Pertanggungjawaban Dokter dalam Transaksi Terapeutik ( Tesis, Pascasarjana Universitas Diponegoro Semarang), 2009.

Kahmad Dadang, Metode Penelitian Agama Cet. I; Bandung: Pustaka Setia, 2000.

Kamus Pusat Bahasa, Kamus Besar Bahasa Indonesia Cet. III; Jakarta: Balai Pustaka, 2005.

Khodija Nyayu, Psikologi Pendidikan Cet. II; Jakarta: Rajagrafindo Persada, 2014.

Koentjoro Tjahjono, Regulasi Kesehatan di Indonesia, Edisi Revisi [t.cet] ; Yogyakarta: C.V Andi Offset, 2011.

Pusat Bahasa Depertemen Pendidikan Nasional, Kamus Besar Bahasa Indonesia.

Sadi Is Muhammad, Etika Hukum Kesehatan Teori dan Aplikasinya di Indonesia, Cet. I; Jakarta: Kencana, 2015

Sani Achmad dan Machfudz Masyhuri, Metodologi Riset Manajemen Sumberdaya Manusia Cet. I; Malang: UIN-Maliki Press, 2010.

Suharmis Arikunto, Penelitian Suatu Pendekatan Praktek Cet. XII; Jakarta: Rineka Cipta, 2002.

Sukandarumidi, Metodologi penelitian: petunjuk praktis untuk peneliti pemula Cet. IV; Jogjakarta: Gadjah Mada University Press, 2012.

Surjadi, Pengembangan Kinerja Pelayanan Publik Cet.I; Bandung: PT Refika Aditama, 2009.

Umar Husein, Metode Penelitian Untuk Skripsi dan Tesis Bisnis Cet. II; Jakarta: Raja Grafindo Persada, 1999.

Wiradarma Danny, Penuntun Hukum Kedokteran, Edisi. 2. Cet. 1; Jakarta: t.p., 2014.

Yunannto Ari dan Helmi, Hukum Pidana Malpraktik Medik [t.c]; Yogyakarta: C.V. Andi Offset, 2010.

\section{Undang-Undang}

Republik Indinesia. Undang-Undang Dasar 1945.

Republik Indonesia. Undang-undang No. 36 Tahun 2009 Tentang kesehatan.

Republik Indonesia. Undang-Undang Nomor 29 Tahun 2004 tentang Praktik Dokter. Republik Indonesia. Undang-undang Nomor 36 tahun 2009, Tentang Kesehatan. 